\title{
The origins of iron-working in India: new evidence from the Central Ganga Plain and the Eastern Vindhyas
}

\author{
Rakesh Tewari*
}

Recent excavations in Uttar Pradesh have turned up iron artefacts, furnaces, tuyeres and slag in layers radiocarbon dated between c. BC 1800 and 1000. This raises again the question of whether iron working was brought in to India during supposed immigrations of the second millennium $B C$, or developed independently.

Keywords: India, Early Iron Age, Iron working, Ganga Valley, Eastern Vindhyas

\section{Introduction}

The date and origin of the introduction of iron artefacts and iron working into India has remained a much debated research problem, not unconnected with the equally debatable question of its association with the supposed arrival, in the second millennium BC, of immigrants from the west, as often suggested on the basis of the Rigveda. Around the middle of the last century, ironworking origins in India were dated to $c .700-600 \mathrm{BC}$ (Gordon 1950; Wheeler 1959). Subsequently, a combination of an association with Painted Grey Ware (PGW) and the advent of radiocarbon dating began to push this date back towards the second millennium BC, a period which had in fact favoured by some scholars earlier in the early twentieth century (Chakrabarti 1992: 10-12).

Considering the radiocarbon dates for the iron bearing deposits at Ataranjikhera in Uttar Pradesh (Table 1) and Hallur in Karnataka, and stratigraphic position of iron in the lower levels mainly at Kausambi near Allahabad, Jakhera in district Etah in the Ganga Valley, and Nagda and Eran in central India, dates around $1000 \mathrm{BC}$ were suggested (Subramanyam 1964; Banarjee 1965; Chakrabarti 1974; Nagarajarao 1974). At the same time Chakrabarti (1974: 354) challenged the view of a western origin, stating "there is no logical basis to connect the beginning of iron in India with any diffusion from the west, from Iran and beyond", and further (1976: 122) "that India was a separate and possibly independent centre of manufacture of early iron."

Since then there has been fresh evidence for even earlier iron-working in India. Technical studies on materials dated $c .1000 \mathrm{BC}$ at Komaranhalli (Karnataka) showed that the smiths of this site could deal with large artefacts, implying that they had already been experimenting for centuries (Agrawal et al. 1985: 228-29). Sahi (1979:366) drew attention to the presence of iron in Chalcolithic deposits at Ahar, and suggested that "the date of the beginning of iron smelting in India may well be placed as early as the sixteenth century $B C$ " and "by about the early decade of thirteenth century $B C$

* Director, U.P. State Archaeological Department, Roshan-ud-daula Kothi, Kaisarbagh, Lucknow 226001 (U.P.) India (Email: rakeshlko@rediffmail.com) 
iron smelting was definitely known in India on a bigger scale". On the basis of four radiocarbon measurements, ranging between $3790+110 \mathrm{BP}$ and $3570+100 \mathrm{BP}$, available for the Megalithic period (without iron) Sharma (1992: 64, 67) has proposed a range of 1550-1300 BC (uncalibrated) for the subsequent iron bearing period at Gufkral (Jammu \& Kashmir).

On the basis of this evidence a date of around 1300/1200 BC has been suggested for the beginning of iron in India and c. $800 \mathrm{BC}$ for the mid Ganga Valley (Allchin \& Allchin 1982: 345; Prakash \& Tripathi 1986: 568; Gaur 1997: 240). Chakrabarti (1992: 68, 164; 1999: 333) has observed that at Ahar it would be the first quarter of the second millennium BC and in Malwa soon after the middle of the second millennium BC. However, the early dates for iron at Ahar are refuted on the grounds of uncertain stratigraphy (Gaur 1997: 244). As far as Komaranhalli is concerned, it is stated that the TL dates have large errors and hence uncertain (Agrawala 2000: 197, 200).

More recently, early contexts containing iron at Jhusi, located on the confluence of the Ganga and Yamuna in district Allahabad, have been dated to 1107-844 cal BC (Tewari et al. 2000: 93). Komaranhalli (Karnataka) has given TL dates in the twelfth - fifteenth century

Table 1. Dates* for early iron-use from Indian sites

\begin{tabular}{|c|c|c|c|c|}
\hline Site & Lab-ref & Date BP & Date cal BC & Pub-ref \\
\hline $\begin{array}{l}\text { Ataranjikhera, district } \\
\text { Etah, Uttar Pradesh }\end{array}$ & TF-191 $\left({ }^{14} \mathrm{C}\right)$ & $\begin{array}{l}2890+110 \\
1155+110\end{array}$ & Ralph & $\begin{array}{l}\text { Agrawal, et al. } \\
\text { 1964: 267; } \\
\text { Gaur 1997: } 241 .\end{array}$ \\
\hline Hallur, Karnataka & $\begin{array}{l}\text { TF-570 }\left({ }^{14} \mathrm{C}\right) \\
\text { TF-573 }\left({ }^{14} \mathrm{C}\right)\end{array}$ & $\begin{array}{l}2970+105 \\
2820+100\end{array}$ & $\begin{array}{c}1385-1050 \\
1125-825\end{array}$ & $\begin{array}{c}\text { Possehl \& } \\
\text { Rissman 1992, } \\
\text { Vol. II: 466; }\end{array}$ \\
\hline $\begin{array}{l}\text { Komaranhalli, } \\
\text { Karnataka }\end{array}$ & $\begin{array}{l}\text { PRL-46 (TL) } \\
\text { PRL-47 (TL) } \\
\text { PRL-47 (TL) } \\
\text { PRL-49 (TL) } \\
\text { PRL-50 (TL) }\end{array}$ & $\begin{array}{l}3300+140 \\
3360+300 \\
3180+280 \\
3110+500 \\
3420+290\end{array}$ & $\begin{array}{l}1320+400 \\
1380+300 \\
1200+280 \\
1130+500 \\
1440+290\end{array}$ & $\begin{array}{c}\text { Deo 1991: 193; } \\
\text { Moorti 1994: } \\
\text { 122-23. }\end{array}$ \\
\hline $\begin{array}{l}\text { Veerapuram, } \\
\text { Andhra Pradesh }\end{array}$ & $\begin{array}{l}\text { PRL-728 }\left({ }^{14} \mathrm{C}\right) \\
\text { PRL-729 }\left({ }^{14} \mathrm{C}\right) \\
\text { PRL-730 }\left({ }^{14} \mathrm{C}\right)\end{array}$ & $\begin{array}{l}2930+140 \\
2890+140 \\
3210+140\end{array}$ & $\begin{array}{c}\text { Stuiver and Reimer } 1993^{*} \\
1374(1186,1183, \\
1128) 921 \\
1293(1047) 899 \\
1679(1493,1476 \\
1458) 1319\end{array}$ & $\begin{array}{c}\text { Deo 199: 193; } \\
\text { Moorti 1994: } \\
\text { 122-23. }\end{array}$ \\
\hline $\begin{array}{l}\text { Ramapuram, } \\
\text { Andhra Pradesh }\end{array}$ & $\begin{array}{l}\text { BS-383 }\left({ }^{14} \mathrm{C}\right) \\
\text { BS-386 }\left({ }^{14} \mathrm{C}\right)\end{array}$ & $\begin{array}{l}3240+110 \\
3280+110\end{array}$ & $\begin{array}{c}\text { Stuiver and Reimer } 1993^{*} \\
1679(1517) 1409 \\
1687(1524) 1432\end{array}$ & $\begin{array}{c}\text { Moorti 1994: } \\
\text { 122-23. }\end{array}$ \\
\hline $\begin{array}{l}\text { Adam, Vidarbha } \\
\text { Maharashtra }\end{array}$ & $\begin{array}{l}\text { PRL-1452 }\left({ }^{14} \mathrm{C}\right) \\
\text { PRL-1456 }\left({ }^{14} \mathrm{C}\right)\end{array}$ & $\begin{array}{l}3080+120 \\
2820+100\end{array}$ & $\begin{array}{c}\text { Stuiver and Reimer } 1993^{*} \\
1393(1205,1205, \\
1188,1181,1149, \\
1144,1129) 917 \\
1490(1381,1334, \\
1321) 1131 \\
1185(973,956,941) 834\end{array}$ & $\begin{array}{l}\text { Unpublished } \\
\text { information } \\
\text { from the } \\
\text { excavator }\end{array}$ \\
\hline
\end{tabular}

\footnotetext{
* These dates are calibrated by Dr B. Sekar, BSIP, Lucknow. References for datasets used: Stuiver, et al. 1998a.
} 
$\mathrm{BC}$, while the radiocarbon dates for early Iron Age sites of Veerapuram and Ramapuram (Andhra Pradesh) are sixteenth - eleventh century cal BC (Table 1) (Deo 1991: 193; Moorti 1994: 122-23) while in Vidarbha region (Maharastra), contexts containing iron have given radiocarbon dates between the fourteenth and tenth centuries cal BC (Table 1).

\section{Recent Findings in Uttar Pradesh}

This paper briefly reports the results of some recent excavations conducted by the Uttar Pradesh State Archaeological Department under the leadership of the present author and their implications for understanding the beginning of iron-working in the Central Ganga

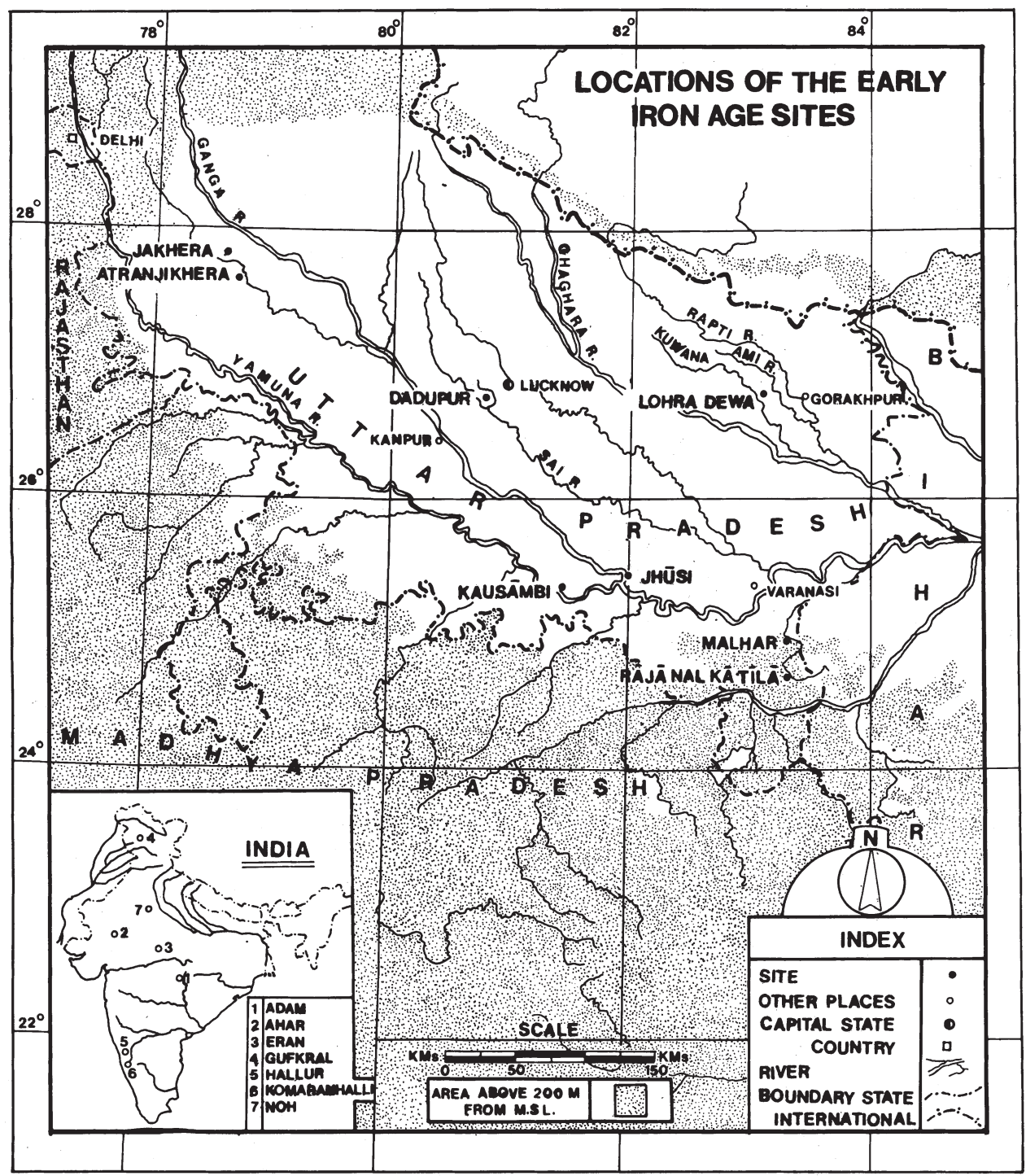

Figure 1. Map showing locations of the Early Iron Age sites in the Central Ganga Plain, the Eastern Vindhyas, and different regions of India. 
Plain and the adjacent part of the Vindhyas. This has further implications in defining the beginning of iron in the subcontinent as a whole. The excavated sites are Raja Nala-ka-tila (199698), Malhar (1998-99), Dadupur (1999-2001) and Lahuradewa or Lohradewa (2001-2002) (Figure 1) Raja Nala-ka-tila (Lat. 24 41' $55^{\prime \prime}$ N.; Log. $83^{\circ} 19^{\prime}$ E.) is located in the upper reaches of the Karamnasa within its loop like meander in district Sonbhadra. The excavations revealed a sequence which

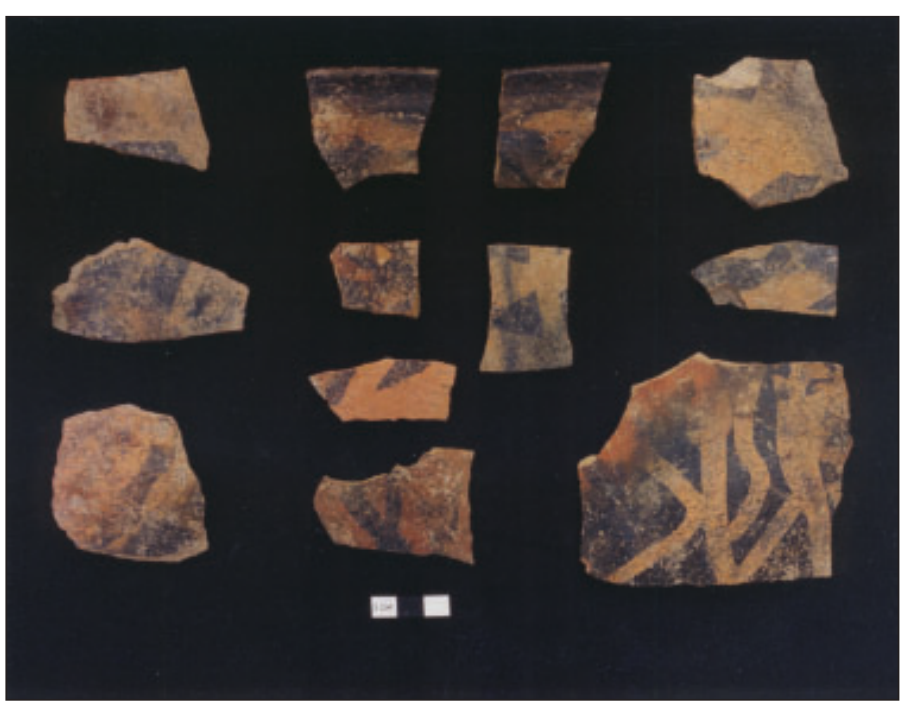

Figure 2. Painted black-and-red ware sherds, from early iron bearing deposits of Period II, Raja Nala-ka-tila, Dist. Sonbhadra. has been divided into four periods (Tewari \& Srivastava 1997; 1998). In Period I, no metal was found and is stratigraphically continuous into Period II. Period III is characterised by the presence of Northern Black Polished Ware (NBPW). Period IV is defined as a Gupta/ post Gupta phase. Iron was found in preNBPW deposits ( 1.5 to $2.00 \mathrm{~m}$ thick) of Period II in association of the pottery hitherto supposed to be the characteristics of the Chalcolithic period, placed between early to late second millennium $\mathrm{BC}$, in the area concerned. The main associated ceramic industries were plain and painted black-andred (Figure 2), black slipped and red wares, in forms which included footed bowl, legged bowl with perforated base, pedestal bowl and button-based goblet. Some sherds also showed cord impressions. Evidence for iron-working included slag and iron artefacts such as a nail, arrowhead, knife and a chisel (Figure 3). Radiocarbon dates for the iron bearing deposits range between 1400 and $800 \mathrm{cal} \mathrm{BC}$ (Table 2).

Since the date for the introduction of iron in the middle and lower Ganga Valley was

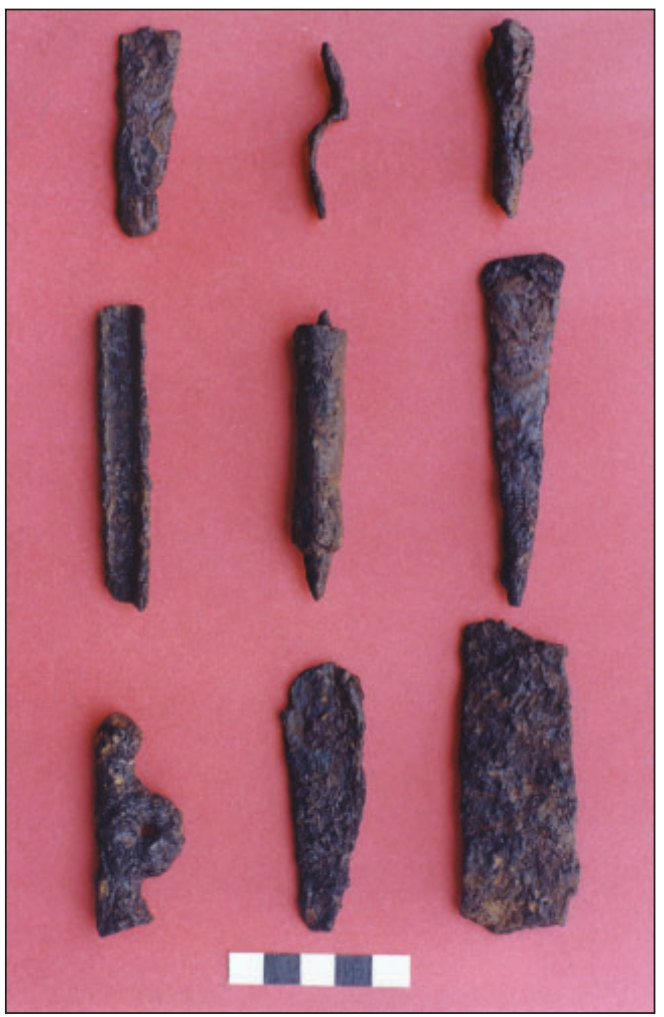

Figure 3. Iron artefacts, from the lower and middle levels of Period II, Raja Nala-ka-tila, Dist. Sonbhadra. 
Table 2. New ${ }^{14} \mathrm{C}$ dates for early iron-use from the Ganga Plain and the Eastern Vindhyas

\begin{tabular}{|c|c|c|c|c|}
\hline Site & Lab-ref & Date BP & Date cal BC & Pub-ref \\
\hline $\begin{array}{l}\text { Raja Nala-ka-tila, } \\
\text { district Sonbhadra, } \\
\text { Uttar Pradesh (U.P.) }\end{array}$ & $\begin{array}{l}\text { BS-1988 } \\
\text { BS-1988 } \\
\text { BS-1378 } \\
\text { BS-1299 } \\
\text { BS-1300 } \\
\text { PRL-2047 }\end{array}$ & $\begin{array}{c}2690+70 \\
2550+110 \\
2830+100 \\
3060+110 \\
2890+80\end{array}$ & $\begin{array}{c}\text { Stuiver and Reimer } 1993^{*} \\
902(828) 800 \\
822(773) 486 \\
1118(963) 859 \\
1423(1307) 1144 \\
1196-1188 \\
1164-1143 \\
1132-976 \\
970-930 \\
1406-1198 \\
1186-1164 \\
1143-1132\end{array}$ & $\begin{array}{l}\text { Tewari et al. } \\
\text { 2000: } 93 \text {. }\end{array}$ \\
\hline $\begin{array}{l}\text { Malhar, district } \\
\text { Chandauli, (U.P.) }\end{array}$ & $\begin{array}{l}\text { BS- } 1623 \text {, } \\
\text { BS- } 1593 \\
\text { (Pit sealed by } \\
\text { Layer No.(3) }\end{array}$ & $\begin{array}{l}3450+90 \\
3540+90\end{array}$ & $\begin{array}{c}\text { Stuiver and Reimer } 1993^{*} \\
1882(1743) 1639 \\
2012(1882,1836, \\
1834) 1742\end{array}$ & $\begin{array}{l}\text { Tewari et al. } \\
\text { 2000: } 88 \text {. }\end{array}$ \\
\hline $\begin{array}{l}\text { Dadupur district } \\
\text { Lucknow, (U.P.) }\end{array}$ & $\begin{array}{l}\text { BS- } 1822 \\
\text { BS- } 1759 \\
\text { BS- } 1825 \text { : } \\
\text { (Pit-sealed by 12) }\end{array}$ & $\begin{array}{c}3270+80 \\
3380+160 \\
3430+90\end{array}$ & $\begin{array}{c}\text { Stuiver and Reimer 1993* } \\
1679(1522) 1442 \\
1882(1685) 1465 \\
1739(1706) 1695\end{array}$ & $\begin{array}{l}\text { Tewari et al. } \\
\text { 2002: } 111\end{array}$ \\
\hline $\begin{array}{l}\text { Lahuradewa, district } \\
\text { Sant Kabir Nagar, (U.P.) }\end{array}$ & BS-1939 & $2940+100$ & $\begin{array}{c}\text { Stuiver and Reimer } 1993^{*} \\
1205,1205,1188 .\end{array}$ & $\begin{array}{l}\text { (Tewari et al. } \\
\text { 2002a: 57) }\end{array}$ \\
\hline $\begin{array}{l}\text { Jhusi, district } \\
\text { Allahabad, (U.P.) }\end{array}$ & PRL-2077 & $2820+80$ & $\begin{array}{c}\text { Stuiver and Reimer 1993* } \\
1107(973,956,941) \\
844\end{array}$ & $\begin{array}{l}\text { Misra, et al. } \\
\text { 2000: } 28 \text {. }\end{array}$ \\
\hline
\end{tabular}

* These dates are calibrated by Dr B. Sekar, BSIP, Lucknow. References for datasets used: Stuiver, et al. 1998a.

being considered as $c .800 \mathrm{BC}$ (above), its appearance in $c .1400 / 1300$ cal BC at Raja Nalaka-tila posed new questions. Realising that this should not be the only site with such early evidence and that there should be examples of experimental iron-smelting which were earlier still, we started a new search. These efforts were rewarded in locating a potential site near a village called Malhar.

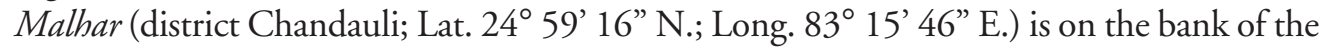
Karamnasa which at this point flows through a rocky, haematite-rich terrain before joining the Ganga near Banaras. The excavations carried out at this site also revealed a sequence of four periods: defined as Period I: Pre Iron; Period II: Early Iron; Period III: NBPW; Period IV: BC 200 to $300 \mathrm{AD}$ (Tewari et al. 2000: 69-98). There is no stratigraphic interval between the layers of Period I and Period II. Iron is present in all the layers of Period II, and identified finds include a nail, clamp, spear-head, arrow-head, awl, knife, bangle, sickle and plough share (examples in Figure 4). As well as iron slag, there were tuyeres and several elongated clay structures, with a burnt internal surface. The ceramic industries of this period are represented by mainly red, black-and-red, black slipped, and grey wares. Red ware and black-and-red ware sherds 
bearing cord impressions on their exterior were found in greater number in the lower levels (Figure 5). The presence of the coarse variety of corded potsherds implies that the iron appeared earlier here than in Period II at Raja Nalaka-tila. This assumption was endorsed by two radiocarbon dates ranging around 1800 cal. BC (Table 2).

The area around Malhar may have been something of a centre of iron production. A small mound, of a kind known locally as lohsan or
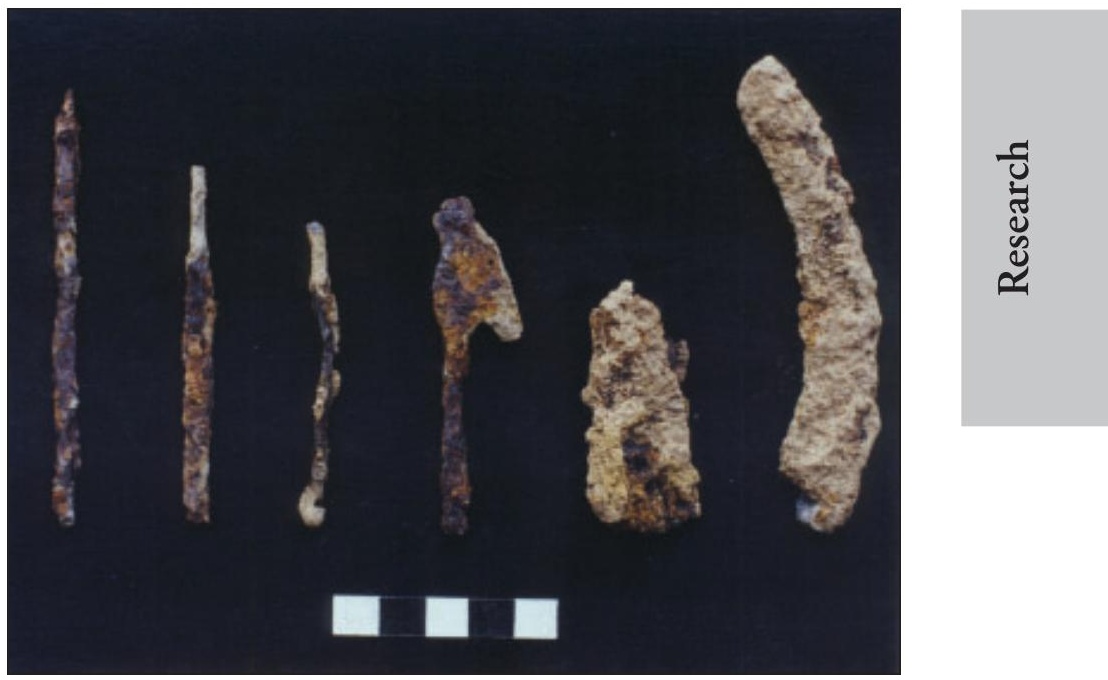
lohsanwa, about $500 \mathrm{~m}$ south to the main site of Malhar, which looks like a heap of iron slag, on excavation revealed two damaged clay furnaces, one of them is illustrated here as Figure 6, filled with iron slag along with a few sherds of the red, grey, and black slipped wares, an axe, and tuyeres. Survey revealed several lohsanwa sites near Musakhand village, the site known as Phakkada Baba located within the Musakhand dam, to the north-west of Malhar, on Baba Wali Pahari (Tewari et al. 2000) and near Naugarh kot (Singh et al. 2000: 143). Plans of damaged clay furnaces within heaps of iron slag along with tuyeres stuck with smelted iron, and potsherds of the grey, black slipped, NBP and red wares were found at these sites. The pottery assemblage at Phakkada Baba also included examples of dish or bowl-on-stand and other forms, comparable to those from Malhar Period II, in red ware, and black-and-red ware. This extraordinary concentration of iron-slag heaps on Baba Wali Pahari and Naugarh kot suggest that large-scale iron smelting activities continued at these sites for a long time.

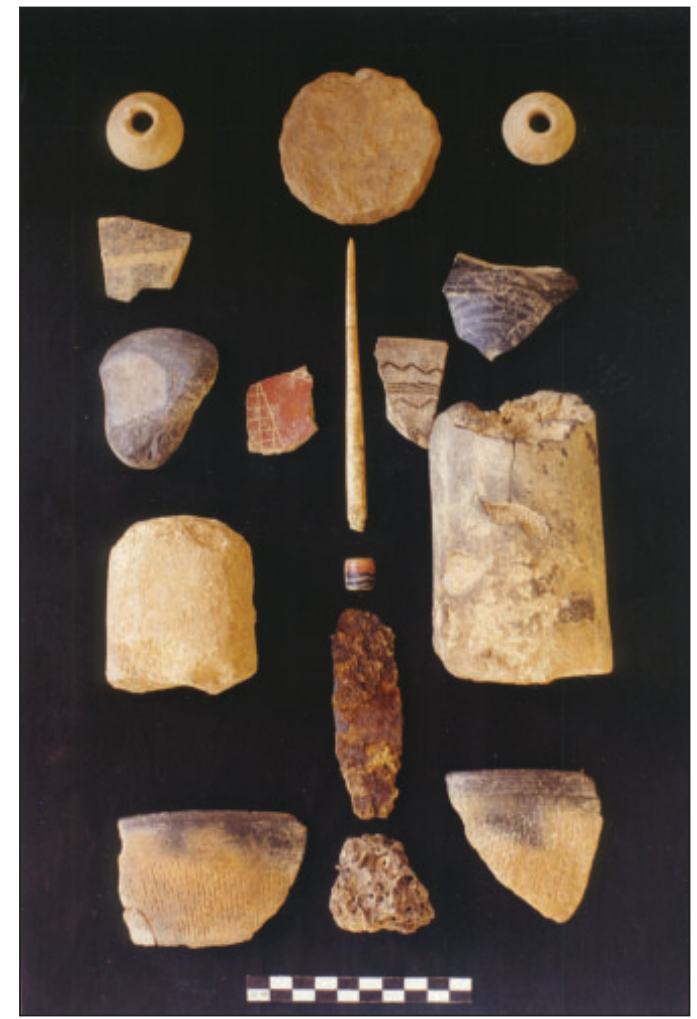

Figure 5. Important cultural components of the early iron bearing deposits, showing corded ware sherds, iron artefact, slag, tuyere, stone and bone artefacts, painted and incised potsherds, stone and terracotta beads. Period II, Malhar, Dist. Chandauli. 
As discussed elsewhere (Tewari et al. 2000) the sites at Malhar, the Baba Wali Pahari, and the Valley are archaeologically linked to the area of Geruwatwa Pahar which appears to have been a major source of iron ore. The Geruwatwa Pahar situated to the southeast of the Baba Wali Pahari, is full of hematite. Villagers reported (as a tradition passed down from several generations), that the agarias

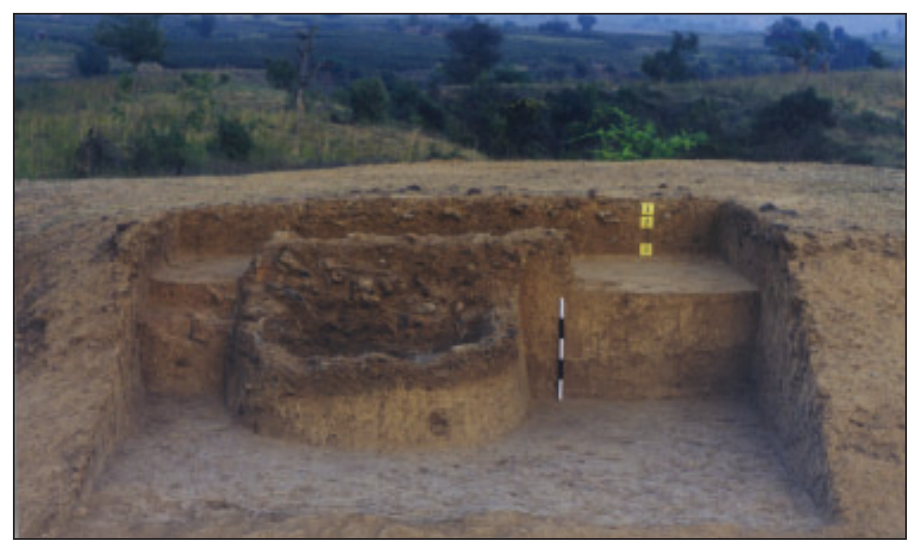

Figure 6. Damaged circular clay furnace, comprising iron slag and tuyeres and other waste materials stuck with its body, exposed at lohsanwa mound, Period II, Malhar, Dist. Chandauli. (a particular tribe known for their iron smelting skills) from Robertsganj side, used to come in this area to procure iron by smelting the hematite. Probably hematite was being primarily smelted at the Baba Wali Pahari and carried over to the valley sites (situated at a distance of about 6-8 km) for secondary smelting. The presence of tuyeres, slags, finished iron artefacts, abovementioned clay structures with burnt internal surfaces and arms, revealed at Malhar, suggest a large scale activity related to manufacture of iron tools. It appears that smelted iron was being carried to this site to manufacture the artefacts and the clay structures were used as the furnaces for forging purposes. Thus this part of the Karamnasa Valley would have been a regional centre for iron production and the Malhar a workshop-site for the manufacturing of the iron artefacts.

Dadupur ( $26^{\circ} 42^{\prime} \mathrm{N}: 80^{\circ} 49^{\prime} \mathrm{E}$ ) is in the valley of the Sai, a minor Ganga tributary near Lucknow. It is the earliest dated site (Tewari et al. 2002:111) between the Gomati and the Sai rivers. The excavations at this

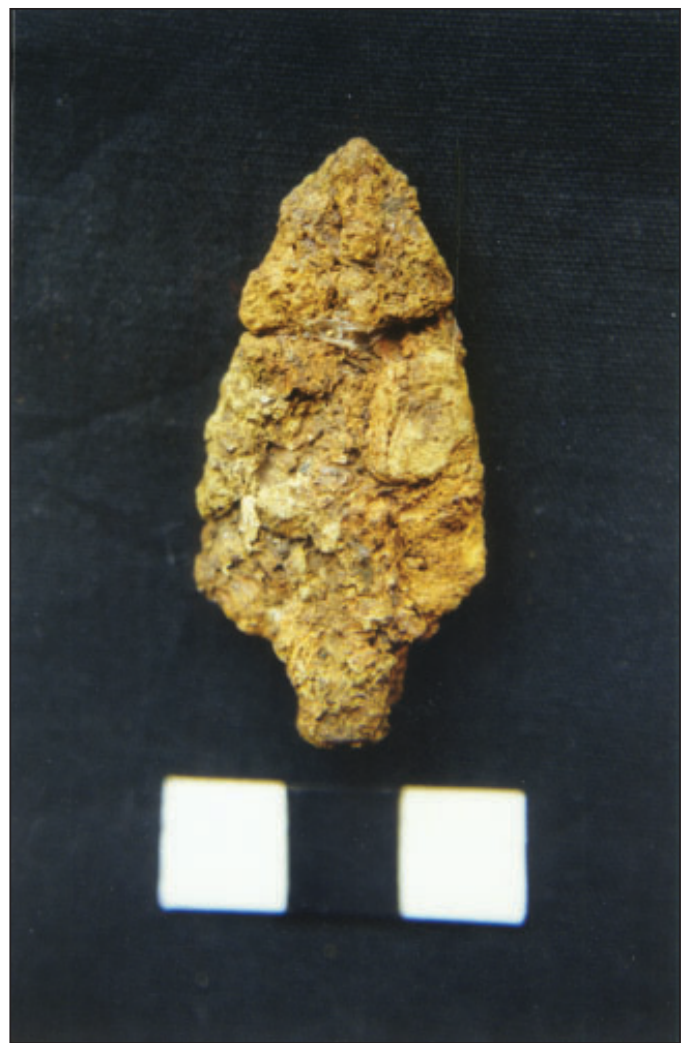

Figure 7. Highly corroded iron arrowhead, Period I, Dadupur, Dist. Lucknow. site have revealed a sequence divided into three periods. The cultural material of Period-I consists of iron artefacts such as the arrowhead shown in Figure 7. Red ware dominates the pottery assemblage of this period, while the 
black-and-red ware is nominally represented. Three radiocarbon dates lie between the eighteenth and sixteenth centuries BC (Table 2). Period II and III are characterised respectively by the presence of Painted Grey Ware (PGW) and NBP ware.

Lahuradewa (district Sant Kabir Nagar; $26^{\circ} 46^{\prime} \mathrm{N}$; 82 $2^{\circ}-57^{\prime} \mathrm{E}$ ) is in the trans-Sarayu plain, the Sarayu being a major tributary of the Ganga. The excavations have revealed new information regarding the early farming cultures of the Sarayupar region, including evidence for the domestication of rice (Oryza sativa) in Period I, radiocarbon dated to $c$. sixth and fifth millennium BC. Associated ceramics include mostly plain and corded, hand made red, and black-and-red, besides, some grey, and black ware sherds. Period II is marked by the appearance of copper. Pottery of the preceding period continued and a new type of pottery, i.e. black slipped ware is added, and the forms include pedestal bowl, and dish or bowl-on-stand. Iron artefacts appear in Period III in the form of corroded nails and other objects. Other components of the assemblage, however, are the same as in Period II. A radiocarbon date obtained for this level was thirteenth - twelfth century BC (Tewari et al. 2002a: 57) (Table 2).

As per K.S. Saraswat's observations (pers.comm.), the carbonised material dated from the sites mentioned above included the branches of some trees, such as Acacia sp., Madhuca indica, Dalbergia sissoo, Treura nudiflora, Boswellia serrata, Aegle marmelos, Syzygium sp., Tectona grandis, Butea monosperma, Logerstroemia sp., Bambusaa sp., etc., and the shrubs like Zixiphus sp., Capparis saparia, Carissa opaca. The above species are in mixed content, with the carbonised remains of leaves, stems and seeds of a number of seasonal herbs and grasses. These tropical vegetations referred to above have generally 60-70 yrs of average life span in case of trees and the shrubs and herbs survive hardly from two to three months to the maximum period of a year or two.

There are other observations on the assemblages from these four sites which might be significant. Copper has been found in a lesser proportion in comparison to iron; presence of burnt clay chunks bearing reed and straw marks and postholes are indicative of wattle and daub houses and thatched huts; associated finds include mainly bone arrowheads, terracotta, stone and steatite (?) beads; some storage bins are dug into the surface and bases of the large earthen storage vessels are represented at Lahuradeawa and Raja Nala-ka-tila; a large quantity of faunal and carbonised archaeo-botanical remains have been recovered at all the sites. As a whole the assemblage is suggestive of well equipped and permanent settlements.

\section{Discussion}

These results indicate that iron using and iron working was prevalent in the Central Ganga Plain and the Eastern Vindhyas from the early second millennium BC. The dates obtained so far group into three: three dates between $c$. 1200-900 cal BC, three between $c$. 1400-1200 cal BC, and five between $c .1800-1500 \mathrm{cal} \mathrm{BC}$. The types and shapes of the associated pottery are comparable to those to be generally considered as the characteristics of the Chalcolithic Period and placed in early to late second millennium BC. Taking all this evidence together it may be concluded that knowledge of iron smelting and manufacturing of iron artefacts was well known in the Eastern Vindhyas and iron had been in use in the Central Ganga Plain, at least from the early second millennium BC. The quantity and types of iron artefacts, and the level of technical advancement indicate that the introduction of iron working took place 
even earlier. The beginning of the use of iron has been traditionally associated with the eastward migration of the later Vedic people, who are also considered as an agency which revolutionised material culture particularly in eastern Uttar Pradesh and Bihar (Sharma 1983: 117-131). The new finds and their dates suggest that a fresh review is needed. Further, the evidence corroborates the early use of iron in other areas of the country, and attests that India was indeed an independent centre for the development of the working of iron.

\section{Acknowledgements}

I am thankful to Dr Rajagopalan and Dr B.Sekar, Birbal Sahni Institute for Palaeobotany, Lucknow for the determination of ${ }^{14} \mathrm{C}$ dates, to Dr Sekar for the calibration of most of the ${ }^{14} \mathrm{C}$ dates, to Dr KS. Saraswat $-\mathrm{a}$ renowned archaeobotanist of the same institution - for the observations regarding the material radiocarbon dated, to Dr P.C. Pant and the Editor, Antiquity for the input to improve the manuscript and to Shri Ram Gopal Mishra and Shri Manmohan Dimri for the figures which illustrate this paper.

\section{References}

Agarwal, D.P. 2000. Ancient Metal Technology and Archaeology of South Asia. New Delhi: Aryan Books International.

Agrawal, D.P., S. Kusumgar \& R.P. Sarna 1964. Radiocarbon dates of Archaeological samples, Current Science 33: 266-69.

Agrawal, O.P., H. Narain ANd G.P. Joshi 1985. Iron Objects from South Indian Megaliths (Karnataka) - A Technological Study and Significance, in Sundara, A. (ed.), Archaeology in Karnataka: 219234. Mysore: Directorate of Archaeology \& Museums.

Allchin, Bridget \& Raymond 1982. The Rise of Civilization in India and Pakistan. Cambridge.

Banarjee, N. R. 1965. The Iron Age in India. Delhi.

Chakrabarti, D.K. 1974. Beginning of Iron in India: Problem Reconsidered, in A.K. Ghosh (ed.), Perspectives in Palaeoanthropology: 345-356. Calcutta: Firma K.L. Mukhopadhyay.

-1976. The beginning of iron in India. Antiquity 4: 114-124.

-1992. The Early Use of Iron in India. Delhi: Oxford University Press.

-1999. India An Archaeological History. Delhi: Oxford University Press.

Deo, S.B. 1991. New Discoveries of Iron Age in India, in C. Margbandhu, K.S. Ramachandran, A.P. Sagar \& D.K. Sinha (eds.), Indian Archaeological Heritage I: 189-97. New Delhi: Agam Kala Prakashan.

Gaur, R.C. 1997. Studies in Indian Archaeology and Ancient India I. Jaipur: Publication Scheme, pp. 238-250.
Gordon, D.H. 1950. The Early Use of Metals in India and Pakistan, Journal of the Royal Anthropological Institute, 55-78.

Moorti, U.S. 1994. Megalithic Culture of South India: Socio-Economic Perspectives, Varanasi, Ganga Kaveri Publishing House.

Nagarajarao, M.S. 1974. Iron Age in South India: Fresh Evidence on Chronology, in A.K. Ghosh (ed.), Perspective in Palaeoanthropology: 357-62. Calcutta: Firma K.L. Mukhopadhyay.

Possehl, G.L. \& P.C. Rissman 1992. The Chronology of Prehistoric India: From Earliest Times to the Iron Age, in R.W. Ehrich (ed.) Chronologies in Old World Archaeology, Vol. I: 465-490; Vol. II: 447474.Chicago and London: The University of Chicago Press.

Prakash, B. \& V. Tripathi 1986. Iron technology in ancient India, Historical Metallurgy: 568-579.

SAHI, M.D.N. 1979. Iron at Ahar, in D.P. Agrawal \& D.K. Chakrabarti (eds.). Essays in Indian Protohistory. Delhi: pp. 365-68.

Sharma, A.K. 1992. Early Iron Users of Gufkral, in Nayak B.U. \& N.C. Ghosh (eds.), New Trends in Indian Art and Archaeology I: 63-68. New Delhi: Aditya Prakashan.

SHARMA, R.S. 1983. Material Culture and Social Formations in Ancient India. Delhi: Macmillan.

Singh, P., R. Tewari \& R. N. Singh 2000. Explorations in Chandauli District (U.P.) $1999-$ 2000: A Preliminary Report, Pragdhara 10: 135148.

Subramanyam, B.R. 1964. Appearance and Spread of Iron in India - An Appraisal of Archaeological Data, Journal of the Oriental institute, Baroda 13: 349-59. 


\section{Rakesh Tewari}

Tewari, R., \& R. K. Srivastava 1997. Excavations at Raja Nala-ka-tila (1995-96), District Sonbhadra (U.P.): Preliminary observations, Pragdhara 7: 77 95.

-1998. Excavations at Raja Nala-ka-tila (1996-97) District Sonbhadra (U.P.): Preliminary Observations, Pragdhara 8: 99-105.

Tewari, R., R.K. Srivastava, K.S. Saraswat \& K.K. SINGH 2000. Excavations at Malhar, District Chandauli (U.P.) 1999: A Preliminary Report, Pragdhara 10: 69-98.
Tewari, R., R.K. Srivastava, \& K.K. Singh 2002. Dadupur Excavations 1999-2000-2001, District Lucknow, Uttar Pradesh: A Preliminary Report, Pragdhara 12: 99-116.

Tewari, R., R.K. Srivastava, \& K.K. Singh 2002a. Excavation at Lahuradewa, District Sant Kabir Nagar, Uttar Pradesh, Puratattva 32: 54-62.

Wheeler, R.E.M. 1959. Early India and Pakistan. London. 